\title{
PROJECT OF COAGULANT DISPENSER IN PULVERIZATION AERATOR WITH WIND DRIVE
}

\author{
Ewa Osuch ${ }^{1}$, Andrzej Osuch ${ }^{1}$, Stanisław Podsiadłowski', Leszek Piechnik ${ }^{1}$, Dawid Chwirot ${ }^{1}$ \\ 1 Institute of Biosystems Engineering, Poznan University of Life Sciences, Wojska Polskiego Str. 50, \\ 60-637 Poznań, Poland \\ * Corresponding author's e-mail: andrzej.osuch@up.poznan.pl
}

Received: 2017.06.11 Accepted: 2017.08.01 Published: 2017.09.01

\begin{abstract}
Lakes are one of most important freshwater ecosystems, playing significant role in functioning of nature and human economy. Swarzędzkie Lake is good example of ecosystem, which in last half-century was exposed to the influence of strong anthropopressure. Direct inflow of sewage with large number of biogens coming to the lake with water of inflows caused distinct disturbance of its functioning. In autumn 2011 restoration bagan on Swarzędzkie Lake for reduction of lake trophy and improvement of water quality. For achieving better and quicker effect, simultaneously combination of some methods was applied, among others method of oxygenation of overbottom water with help of pulverization aerator and method of precise inactivation of phosphorus in water depths. Characterization and analysis of improved coagulant dispenser applying active substance only during work of pulverization aerator is the aim of this thesis. Principle of dispenser work, its structure and location in pulverization aerator were explained. It was stated that introduction to water a factor initiating process of phosphorus inactivation causes significant reduction of mineral phosphorus in water and size of coagulant dose correlates with intensity of work of pulverization aerator with wind drive.
\end{abstract}

Keywords: eutrophication of lakes, lakes restoration, inactivation of phosphates, pulverization aerator.

\section{INTRODUCTION}

Water ecosystems are one of the most important environments of life on the Earth. Specific formations of biocenosis continuously undergo transformations in natural conditions or in conditions, where the influence of human is pointed out. Lakes on account of many ecological, recreational and usable advantages are particularly close for human. Therefore, these areas of water are exposed to many negative consequences of anthropogenic activity. There are many ways of cleaning water reservoirs, there are among others method of artificial aeration of water or chemical inactivation of phosphorus. Bottom sediments, which undergo mineralization, use oxygen dissolved in water depths, what inevitably leads to arising deficit of oxygen in water reservoir [Podsiadłowski 2008]. So aeration of deep layers is necessary process, because it results improvement of oxygen conditions, which are necessary for proceeding other operations of restoration, especially inactivation of phosphorus. Chemical precipitations of phosphates from water to bottom sediments is extremely important, because they are one of the most important compounds causing eutrophication of lakes.

Excessive inflow of contaminants can lead to biological imbalance and loss possibility of self-cleaning by water environment [Chełmicki 2001]. Current water as well as limnic water have the ability of self-cleaning. In the first kind of water processes of biochemical transformation of organic compounds in inorganic com- 
pounds through oxygen bacteria play a larger role [Stańczykowska 1997], in stagnant water sedimentation of solid particulates. In both cases assimilation of contaminants by living organisms is very important [Rzętała et al. 2013]. It is considered that full ability of surface water for self-cleaning can be retained, if proportion of supplied sewage to clear water of reservoir amounts maximally 1:50 [Kajak 2001]. Lakes undergo easier degradation caused by excessive discharge of contaminants than rivers, where water undergoes continuous exchange. Susceptibility of these reservoirs to degradation is important for their protection. Research in year 1997 appraised 115 lakes and until $20 \%$ of them were beyond classification [Chełmicki 2001]. The process of eutrophication is considered one of the most serious threats for water ecosystems. Water reservoir, in which this process occurs, loses its industrial, food (water is not suitable for drinking) and recreational susceptibility [Kuczera 2008]. It follows from definition contained in Hydrobiological Dictionary [2002], that the essence of this process is growth of concentration of biogenes, what causes pace growth of production of organic matter. Accelerated development of phytoplankton and higher plant forms causes undesirable biological disturbances, by what water quality in the reservoir deteriorates. Water loses its transparency, content of oxygen falls and simultaneously methane and hydrogen sulphide with unpleasant smell are exhaled. There are many reasons of eutrophication, among others, contaminants coming from territorial sources (inflow of biogenic elements as a result of wind erosion and water erosion), contaminants caused by agriculture (plant protection products, fertilization, incorrect melioration) or spot sourcesdischarges of industrial and municipal sewage directly to lake or to river, which supplies lake [Podedworna and Marciniewicz 2004].

In a prevalent number of cases, water reservoirs in Poland are in an advanced phase of development of eutrophication, what requires application of special techniques of restoration. To the most often applied methods belong: [Lossow 1998; Podsiadłowski 2008]:

- removal of bottom sediments

- rinsing lakes

- exchange of water mass(possible only in the case of small reservoir)

- aeration water during introduction air to hypolimnion and metalimnion (deep layers)
- chemical precipitation of phosphates from water to bottom sediments, inactivation biogenic compounds

- removal water from deep layers

- interventions of biomanipulation

- revitalization zone of littoral (planting macrophytes)

Restoration eutrophic water areas largely consists in reducing concentration of compounds of phosphorus, it allows to set positive changes in motion, such as limitation of development of algae, growth of water transparency and stabilization of bottom sediments Elimination of phosphates can take place in two directions [Jerzy and Wysocki 2006]:

- biological method,

- physicochemical method.

Clay solutions, ferric solutions(PIX) or solutions containing aluminum are very popular preparations used in a method of elimination of phosphates through binding them in hard soluble sediments. In first variant coagulant, which is water solution of polyaluminum chloride is used, lanthanum has high efficiency of binding ions $\mathrm{PO}_{4}^{3-}$. It happens so because phosphates bind themselves with this element in molar proportion 1:1, according to reaction [Helman-Grubba 2006]:

$\mathrm{La}^{3+}+\mathrm{PO}_{4}^{3-} \rightarrow \mathrm{LaPO}(4)$

Lanthanum being component of preparation can react with phosphate anions in water or remain in structure of clay and in such a form in the wide range of changing physicochemical conditions. Created as a result of reaction lanthanum phosphate $(\mathrm{V})$ is salt of phosphoric acid and lanthanum occurring very rare in nature. This mixture makes impossible to release again phosphorus contained in bottom sediments. Combination of phosphorus and lanthanum is solid and does not depend on oxygen conditions, which reign in water [Chróst 2015]. It is particularly important in case of reservoirs, where possibility of performing artificial aeration of water, for example sewage treatment plants, does not exist. It resulted unequivocally from the conducted research that a preparation containing lanthanum has complex effect and insignificant impact on the natural environment [Helman-Grubba 2006]. High effectiveness of inactivation of phosphorus can be achieved only in conditions of oxygened water. Chemical interventions of precipitation of phosphorus are completely safe for biological life of a lake. They cause reduction of the amount 
of biogenic compounds, what extensively holds back the intensity of development of algae and noticeably improves the quality of water [Rybacki et al. 2016]. Chemical reactions of process of inactivation phosphates:

$$
\begin{aligned}
& 3 \mathrm{FeSO}_{4}+2 \mathrm{PO}_{4}^{3-} \rightarrow \mathrm{Fe}_{3}\left(\mathrm{PO}_{4}\right)_{2}+3 \mathrm{SO}_{4}^{2-} \\
& \mathrm{FeCl}_{3}+\mathrm{PO}_{4}^{3-} \rightarrow \mathrm{FePO}_{4}+3 \mathrm{CL}(-)
\end{aligned}
$$

As a result of chemical reactions salts of phosphoric acid come into being. In the first reaction iron(II) phosphate(V) inorganic compound is created. It is insoluble in water and is characterized by adoption of light blue crystals in room temperature. It results from previously done research that coagulant lays out unevenly, creating locally islets on bottom sediments. It is caused by little possibility of buoyancy and by the structure of coagulant [Rybacki et al. 2016]. Precipitation of phosphorus from water depths to sediments is not only its chemical binding in insoluble iron phosphates, but also it consists in sorption of phosphate ions through precipitating iron hydroxide and oxygened sediments. Compounds of iron exist naturally in water ecosystems, because they reach there from the catchment area with ground water and surface water. When large fertility and deoxygenation of over-bottom layers are achieved, their precipitation to sediments in a form of insoluble sulphides occurs. However, then completion of water depths in this elements is necessary, especially in summer period, because at this time supply from catchment area is significantly reduced [Gołdyn and Podsiadłowski 2009].

Advantages of restoration by method of inactivation of phosphorus[Rybacki et al. 2016]:

- low cost in relation to other methods of restoration,

- reduction of amount of phosphorus in reservoir,

- improvement of transparency of water,

- reconstruction and development of bottom vegetation,

- significant reduction of cyanosis blooms.

Placed on the bottom complexes of phosphorus with iron or aluminum are insoluble and stable only in oxygened environment. In conditions of lack of oxygen they become soluble again, so phosphorus is released to water and bottom sediments again, by what water environment is fertilized [Chróst 2015]. Such a course of inactivation is obviously undesirable because it gets short-lived effect of restoration, therefore, a com- bination of methods of artificial aeration of water and introduction coagulant to reservoir is the best. Progressive process of eutrophication and lack of self-acting cleaning water in reservoir in connection with insufficient phenomenon of mechanical interference of water result sedimentation of organic and inorganic suspension on the bottom of reservoir, creating bottom sediments. These sediments undergo mineralization, by what they use oxygen dissolved in water depths [Podsiadłowski 2008]. Two main kinds of artificial aeration are applied: with thermal destratification and without devastation of stratification. The first way assumes that mixing cold water of hypolimnion with warm water of epilimnion will cause sufficient oxygenation of water stored in deeper layers of reservoir. Mixing these layers is caused by provision on the bottom of lake compressed air, which pushes out cold water of deep zones and mixes it with warmer surface zones. Instead, the second way does not bring any changes in the thermal system of lake. Oxygenation of hypolimnion without raising temperature of being there water [Lossow 1998]. To ensure oxygenation of these layers, mainly hypolimnion, above all aerators are applied. Pulverization aerator does not pump in air to water, but sucks in water from deoxygenated bottom zones, next it aerates water, enabling simultaneously prominent diffusion of gases and finally drains oxygened water back to the zone of the intake [Gołdyn and Podsiadłowski 2009]. Aerators can be divided on the account of the principle of operation on pneumatic-diffuser aerators and pulverization aerators. Pneumaticdiffuser aerators are applied less often, because air is pumped into a layer of water, in which large concentration of hydrogen sulphide and methane is, by what they are ineffective and simultaneously significantly energy-intensive. Pulverization aerators show a number of advantages in comparison with pneumatic-diffuser aerators. They have simply construction and essence of operation is based on pulverization of water in air. Pulverization water in atmospheric air is essential advantage of these aerators, so the process of diffusion of gases proceeds much easier because pulverization of water occurs in conditions of the excess of oxygen. Pulverization aerator with wind drive uses energy produced thanks to wind turbine of Savonius. Application of such a solution was possible thanks to insignificant request on power by aerator. Turbine of Savonius is characterized by simply construction and, what is important, in- 
sensitivity on variability of wind direction. Drive of pulverization wheel is transferred by belt transmission. Additionally, during work of rotor, force of Coriolis occurs, which influences profitably general stability of raft of aerator [Gołdyn and Podsiadłowski 2009]. Energy produced by wind engine, rotor engine is in the majority used for diffusion of gases - release of hydrogen sulphide and saturation of hypolimnion water by oxygen [Podsiadłowski 2008]. Water flowing by aerator is characterized by larger oxygenation, even sevenfold, it allows to create the so-called zone of intensive aeration.

Pulverization aerators are characterized by large efficiency of oxygenation and simultaneously this efficiency falls only slightly with the growth of work depth, what undoubtedly has an enormous importance in case of deep lakes.

Pulverization aerators supplied by wind energy provide systematically oxygen to over-bottom layer of lakes, what enables inactivation of phosphorus exhaled in the effect of so-called emission of bottom [Podsiadłowski,2008]. In year 2003 such an aerator was equipped with system of inactivation of phosphorus. Research took place on Municipal Lake in Chodzież. This system enabled dosage of preparation(coagulant) depending on efficiency of pulverization. Determination of correlation between dosage of coagulant and efficiency of aeration and velocity of wind was main purpose of done research. It facilitated correct regulation of the system of phosphorus inactivation. From carried out experiments it resulted unequivocally, that intensity of pulverization is closely related to velocity of wind and it influenced amount of coagulant dosed to oxygened lake water.

\section{DESIGN OF COAGULANT DISPENSER}

Elaboration of design of coagulant dispenser in pulverization aerator, which will introduce coagulant only during work of pulverization aerator was the purpose of research.

Measurements were performed on pulverization aerator with wind drive located on Swarzędzkie Lake in Swarzędz. The lake about the surface of 0,94 square kilometer, maximal depth 6,5 meters and average depth 2,6 meters is located on Wrzesińska Plain. In the north part of the town of Swarzędz. The research conducted in years 2000-2002 stated that Swarzędzkie Lake as most of lakes in Wielkopolska region is strongly eutrophic reservoir. Monitored parameters of water cleanness confirmed high content of nutrients, especially nitrates and phosphates and insufficient amount of oxygen [Kowalczewska-Madura and Gołdyn 2006]. Such situation caused, that eutrophication developed quickly, by what decision about restoration of lake was made. From July 2011 year lake is exposed to restoration by method of pulverization aeration with system of phosphorus inactivation.

The most important issue is to dose active substation only then, when aerator works. For that reason elaboration of such a device, which fulfils this aspect and does not require power by „foreign" energy (electrical, mechanical or pneumatic) by simultaneous precise dosage of coagulant was aim of thesis. Coagulant applier is installed to container of oxygened and degassed water of pulverization aerator and contains a valve closing the outlet from the container winded on connecting stub pipe of container of applier and valve contains body with at least one outflow hole and winded on body nut with through-hole of needle, by which goes through needle connected permanently with gland, which adheres to outlet of container and between gland and internal surface of nut is installed spring with regulated degree of tension. At the end of the needle opposite in relation to gland a hollow disc and in its bottom is placed permanently and at least one blow-off hole is made. A nut with a through-hole, by which the needle goes through, ensures regulation of the degree of spring tension. Degree of screwing or unscrewing in relation to the body of valve shortens (squeezes) or lengthens (expands) the spring. The spring is tensed to the value resulting from physicochemical research of water in water reservoir, which is threshold, by which without additional load, release of gland and outflow of coagulant don't occur. On side opposite in relation to valve, container of coagulant has closed hole for completion of level of active substance. During the work of pulverization aerator, water taken from the bottom of water reservoir is dissipated by blades of aerator falls gravitationally to container of oxygened and degassed water of aerator, simultaneously it accumulates on disc connected with the needle. As a consequence of the impacts and accumulation of water drops on disc, needle moves so, that gland opens outflow hole of container and coagulant drains to interior of body of valve, next by at least one hole in body outside 
water, which is led off by the aerator to the inferior zone of water reservoir. When wind stops and aerator does not work, water is not splashed on the surface of disc and therefore the force necessary for shortening the spring is too small and the container of coagulant remains closed, so the coagulant is not dosed.

Such a location of the device ensures that it will fulfil constructional assumptions concerning direct and precise dosage of coagulant to oxygened water. Application of coagulant to such water ensures the most effective binding phosphorus to bottom sediments of the lake, this fact was confirmed by analysing many examinations contained in numerous positions of literature. Using artificial material was assumed for building a container for work liquid, because this material is highly resistant to chemicals, corrosion and has a tolerance of a large range of temperatures. Simultaneously, such a container can be easily adjusted to needs of project. Maximal sizes of container were determined on the grounds of measurements performed in the field. Limitation of size of container is conditioned by location of installation of device. Opened cover, in which dispenser has to be installed limits height (maximally 600 $\mathrm{mm}$ ) and width (maximally $200 \mathrm{~mm}$ ) of container. Instead length (maximally $300 \mathrm{~mm}$ ) of container depends on size of space between blades of pulverization wheel and device itself. In disc with concavity holes will be drilled for assurance outlet of water, which will be accumulated there.

Figure number 1 presents the location of improved coagulant applier. It explains earlier made constructional assumptions concerning size of container for work liquid. Dispenser cannot disrupt the course of aeration process , so space between blades of pulverization wheel and applying device has to remain. Such a solution also allows drops of water to fall down freely on a hollow disc located under container of coagulant and just above the surface of oxygened water.

Simplicity of construction of the applier is based on a small number of mobile elements. Substantially, the only mobile elements are spring and needle. The needle is connected with gland from one side and with a hollow disc from other side making reciprocating movements in vertical plain.

\section{CONCLUSIONS}

The carried out analyses, measurements and observations allowed to define the following conclusions:

1. Level of contamination of lakes in Poland is not optimistic, however, better and better water and sewage management and made attempts of cleaning surface water bring many positive changes, above all restoration of valuable recreational advantages of water reservoirs.

2. Construction of the applier ensures precise dosage of coagulant only during the work of pulverization aerator and safe storage of preparation.

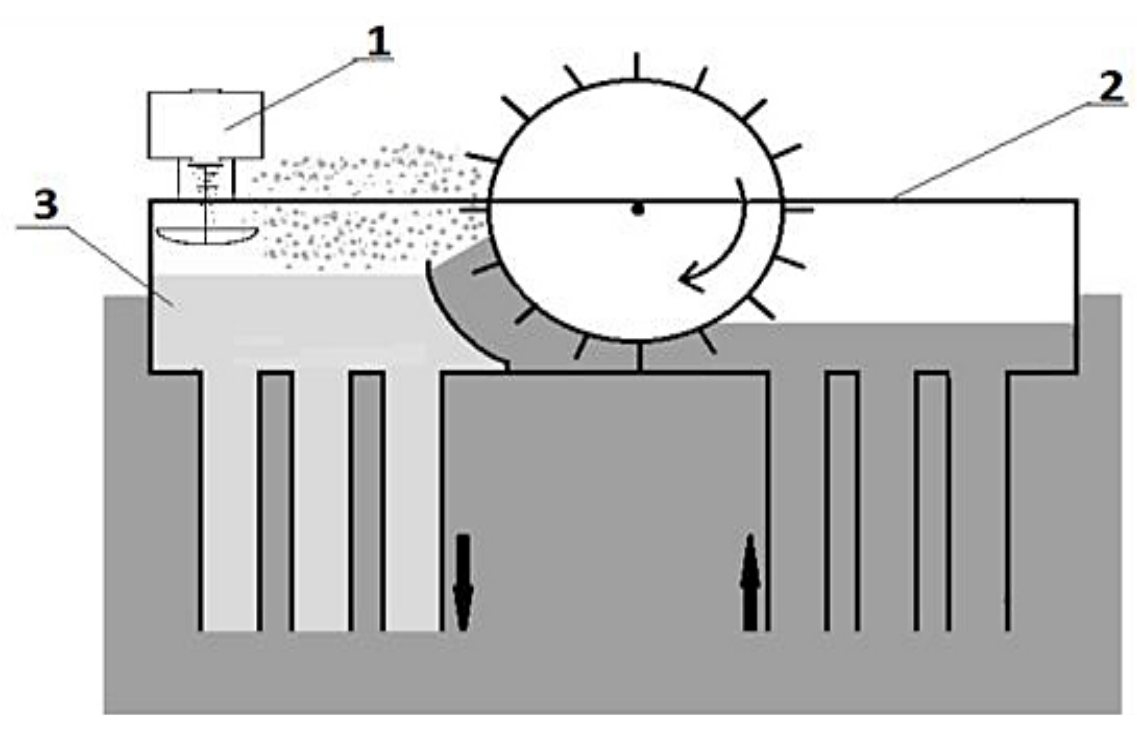

Figure 1. Location of coagulant applier in pulverization aerator with wind drive 1 - coagulant applier, 2 - frame of pulverization aerator, 3 - container of oxygened and degassed water [Podsiadłowski 2008] 


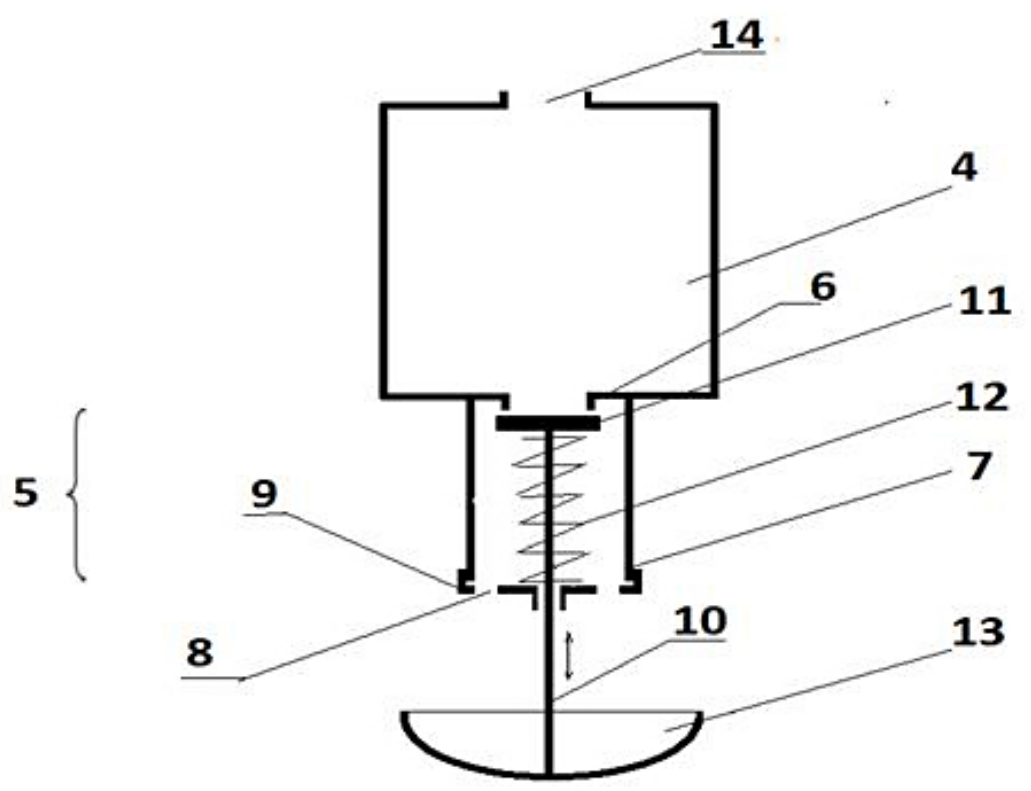

Figure 2. Schematic diagram of coagulant dispenser 4 - container for active substance, 5 - valve, 6 - outlet of coagulant, 7 - body, 8-outflow holes, 9 - nut, 10 - needle, 11 - gland, 12 - spring, 13 - disc with concavity, 14 - hole for completion of coagulant level

3. Introduction of a factor initiating process of inactivation of phosphorus to water causes significant reduction amount of mineral phosphorus in water and size of dose of coagulant correlates with the intensity of work of pulverization aerator with wind drive.

Summarizing, on account of extremely complicated processes occurred in water ecosystems, unceasing search for innovatory solutions of protection and restoration of water reservoirs is needed. Because of too large intervention by human, natural processes of cleaning is not effective enough. The state of Polish lakes raises a question if the restoration processes have become outdated. Now asking a question: when and how to clean Polish water reservoirs. Progressive quickly undesired processes exert enormous pressure of time, because restoration of contaminated water areas is long and arduous. The hoice of appropriate and consequently the most effective method also provides quite large problems. Designing improved applier of coagulant in order to inactivate phosphorus brings many benefits for quick restoration of good ecological state of lakes.

\section{REFERENCES}

1. Chełmicki W. 2001. Woda - Zasoby, degradacja, ochrona, Wyd. Naukowe PWN, Warszawa.
2. Chróst R. 2015. Dlaczego bioremediacja mikrobiologiczna? Kompleksowa bioremediacja mikrobiologiczna w porównaniu z klasycznymi metodami rekultywacji jezior najczęściej stosowanymi w Polsce. Rekultywacja jezior poznańskich, Poznań.

3. Gołdyn R., Podsiadłowski S. 2009. Metody zrównoważonej rekultywacji jezior. Wielkopolski Biuletyn Ekologiczny, 3.

4. Helman-Grubba M. 2006. Rekultywacja zdegradowanych akwenów przez inaktywację fosforanów za pomocą preparatu zwierającego lantan. Przegląd Komunalny, 9, 70-71.

5. Jerzy J., Wysocki J. 2006. Fizykochemiczne uwarunkowania eliminacji fosforanów z wód powierzchniowych. Przegląd Komunalny, 9, 72-73.

6. Kowalczewska-Madura K., Gołdyn R. 2006. Antropogenic changes in water quality in Swarzędzkie Lake (West Poland). Limnological Review, 147-154.

7. Kuczera M. 2005. Eutrofizacja- techniczne sposoby zapobiegania i rekultywacji zbiorników wodnych. Ekopartner, 5, 24-25.

8. Lossow K.1998. Ochrona i rekultywacja jezior teoria i praktyka. Idee Ekologiczne. Seria Szkice, 7, 13, 55-70.

9. Podedworna M., Marciniewicz M. 2004. Metody rekultywacji jezior zeutrofizowanych. Ekopartner, $11,14-15$.

10. Podsiadłowski S. 2008. Wstępne badania aeratora pulweryzacyjnego, wyposażonego w system inaktywacji fosforu. Zeszyty Problemowe Postępów Nauk Rolniczych, 528, 439-447 
11. Rybacki P., Ratajczak J., Osuch E., Osuch A. 2016. Analiza procesu inaktywacji jonów fosforowych w wodzie Jeziora Durowskiego. Inżynieria Ekologiczna, 47, 33-39.

12. Słownik hydrobiologiczny. 2002. Wydawnictwo Naukowe PWN, Warszawa.

13. Rzętała M.A., Jaguś A., Rzętała M. 2013. Antro- pogenic changes in water qua-lity in Swarzędzkie Lake. Ann. Set the Environ. Prot., 15, 2510-2525.

14. Stańczykowska A. 1997. Ekologia naszych wód. Wyd. Szkolne i Pedagogiczne, Warszawa.

15. Kajak Z. 2001. Hydrobiologia-Limnologia. Ekosystemy wód śródlądowych, Wyd. Naukowe PWN, Warszawa. 